\title{
Armed Attack against the Military Force of an International Organization and Use of Force in Self-Defence by a Troop-Contributing State: A Tentative Legal Assessment of an Unlikely Scenario
}

\author{
Paolo Palchetti \\ Associate Professor of International Law, University of Macerata, Italy \\ email: palchetti@unimc.it
}

\begin{abstract}
If the military force of an international organization is made the object of a military attack by a State, that international organization may be regarded as being entitled to use force in self-defence. However, since the forces of international organizations are generally composed of national contingents which States put at the disposal of the international organizations, the question may be raised as to whether, in case of an armed attack against such forces, the sending State would also be entitled to use force in self-defence to protect its national contingent. This question, which was addressed, albeit in a very cursory manner, in the 2009 Report of the EU Independent International Fact-Finding Mission on the Conflict in Georgia, has to be answered taking into account the status of national contingents as organs of the sending States. By attaching relevance to the contingent's dual status and to the rationale underlying the rule on self-defence, this study argues that whenever the national contingent is made the object of an armed attack the possibility for the sending State to invoke self-defence cannot be excluded. In particular, the invocability of self-defence by the sending State should be admitted in those cases in which the armed attack is clearly aimed at targeting that State.
\end{abstract}

\section{Keywords}

International organizations, peacekeeping operations, troops-contributing States, use of force, self-defence 


\section{Introduction}

The use of force in self-defence by an international organization still remains, to a large extent, an abstract subject. Practice is rare. The fact that such practice mainly concerns the activities of United Nations peacekeeping forces seems to further complicate matters: given the special role and functions of the United Nations, and the difficulties sometimes to identify a clear dividing line between use of force in self-defence and use of force for collective security purposes, the practice of the United Nations in this respect may not always lend itself to an easy generalization.

Despite the lack of clear indications from practice, there is wide support in international legal literature to the idea that international organizations which are victims of an armed attack are entitled to use force in self-defence. ${ }^{\mathrm{I}}$ This view is generally based on the argument that, if international organizations find themselves to be confronted with situations of armed attack comparable

r) Finn Seyersted, "United Nations Forces: Some Legal Problems”, 37 British Yearbook of International Law (196I), p. 472; Mahnoush H. Arsanjani, "Claims Against International Organizations: Quis custodiet ipsos custodes?", 7 The Yale Journal of World Public Order (198I), p. 176; Olivier Corten and Pierre Klein, "Action humanitaire et Chapitre VII: La redéfinition du mandat et des moyens d'action des forces des Nations Unies", 39 Annuaire français de droit international (1993), p. I22; Pierre Klein, La Responsabilité des Organisations Internationales (Bruylant, Brussels, 1998), p. 419 et seq.; Trevor Findlay, The Use of Force in UN Peace Operations (Oxford University Press, Oxford, 2002), p. 15; Christian Dominicé, "La responsabilité internationale des Nations Unies", in Jean-Pierre Cot et al (eds.), La Charte des Nations Unies, Commentaire article par article (Economica, Paris, 3rd ed., 2005), p. 158; Emmanuel Roucounas, "Present Problems of the Use of Force in International Law: Sub-group on Self-defence: Provisional Draft", 72-I Annuaire de l'Institut de Droit International (2007), p. I27. The resolution on "Present problems of the use of force in international law: A. Self-defence", adopted by the Institut de Droit International in 2007 at the session of Santiago, does not address the question of the invocability of self-defence by an international organization; it simply observes that the problem "of the relationship between self-defence and international organizations" required "further study from the Institute" (the text of the resolution is available at <www.idi-iil.org $>$ ). It must be observed that, particularly with regard to the use of force by United Nations peacekeeping operations, the notion of self-defence is often used to refer to the personal right belonging to peacekeepers to defend themselves against attacks; it also includes the 'defence of the mandate'. This notion of self-defence must be kept distinct from the right of self-defence belonging to a State or to an international organization in case of armed attack by another State. On this distinction see Klein, La responsabilité des organisations internationales, supra, p. 42I. In the present article the notion of self-defence is used to refer to the military response by a State or an international organization against an armed attack. 
to those which justify a reaction in self-defence by a State, then there is no reason to deny them the possibility to resort to force to repel the attack. ${ }^{2}$ Most recently, the invocability of self-defence by international organizations has been acknowledged by the International Law Commission. Article 20 of the Draft Articles on the Responsibility of International Organizations, adopted on first reading in 2009, provides that " $[\mathrm{t}]$ he wrongfulness of an act of an international organization is precluded if and to the extent that that act constitutes a lawful measure of self-defence under international law". ${ }^{3}$ Interestingly, in their comments to the Commission's work, States did not manifest opposition against this provision. While several States observed that the right of self-defence possessed by international organizations may not have the same scope as the right of self-defence possessed by States, the majority of opinions expressed on this subject appeared to accept the idea that, under certain circumstances, international organizations may be considered to be entitled to resort to force in self-defence. ${ }^{4}$

Situations which may conceivably amount to an armed attack against an international organization are restricted to a few cases. Leaving aside the case of an international organization administering a territory, the most likely, if not the only, situation is when the armed force of an international organization is made the object of a military attack by a State..$^{5}$ As is well known, Article 3(d) of General Assembly Resolution 3314 (XXIX) on the

2) See, e.g., Giorgio Gaja, Fourth Report on the Responsibility of International Organizations, A/CN.4/564, p. 5 .

3) Report of the International Law Commission, Sixty-first Session, A/64/ıo, p. 95. The text adopted in 2009 slightly differs from the text previously adopted by the International Law Commission in 2006, which provided that " $\mathrm{t}]$ he wrongfulness of an act of an international organization is precluded if the act constitutes a lawful measure of self-defence taken in conformity with the principles of international law embodied in the Charter of the United Nations". See Report of the International Law Commission, Fifty-eighth Session, A/6I/IO, p. 265 .

4) For a summary of the positions held by States in their comments to Article I8 of the Draft Articles on the Responsibility of International Organizations, see Giorgio Gaja, Seventh Report on the Responsibility of the International Organizations, A/CN.4/610, pp. 20-2I.

5) For the view that "ce type de situation recouvre en fait l'essentiel des hypothèses dans lesquelles la force est utilisée à l'encontre d'organisations internationals", see Klein, supra note I, p. 420. The view that the United Nations would be entitled to invoke self-defence in the case in which an armed attack takes place against a territory administered by them is held by Dominicé, supra note I, p. I58. See also Gaja, supra note 4, p. 2I. 
"Definition of Aggression" provides that an attack by the armed forces of a State on the land, sea, or air forces of another State qualifies as an act of aggression. Resolution 3314 (XXIX) only refers to attacks against the armed force of a State; however, it is reasonable to assume that the same act should equally be qualified as aggression even if it was directed against the armed force of an international organization.

While an international organization can lawfully take military measures to defend its armed force against the attack of a State, it may be asked whether in such a situation the organization is also the only subject entitled to invoke self-defence. Armed forces of international organizations usually have a complex legal status. The invocability of self-defence by an international organization is premised on the fact that the armed force is an organ of that organization and, when attacked, was performing the functions assigned to it by the organization. However, these forces are generally composed of national contingents which States put at the disposal of the international organizations. Even if national contingents are placed under the operational command of an organ of the organization, as in the case of United Nations peacekeeping forces, they remain in their national service and the sending States retain significant powers over their troops. Because of the permanence of these links between a national contingent and the sending State, one may wonder whether a State, when contributing troops to the armed force of an international organization, retains the right to exercise some form of protection in respect to these troops and in particular whether this protection also includes the right of self-defence when the national contingent is subject to an armed attack by another State.

The question of whether a State may use force to protect a national contingent forming part of a peacekeeping mission under international mandate has been recently addressed in the Report released on September 2009 by the EU Independent International Fact-Finding Mission on the Conflict in Georgia. ${ }^{6}$ While the situation addressed by the EU Fact-Finding Mission did not concern a national contingent put at the disposal of an international organization, the Report also contains some interesting, albeit cursory, considerations regarding this type of situations. An assessment of

6) The Independent International Fact-Finding Mission on the Conflict in Georgia was established by the European Union Council with its decision 2008/90I/CFSP of 2 December 2008. The Report of the Fact-Finding mission is available at <www.ceiig.ch $>$. 
the approach followed by the EU Mission may therefore provide a useful starting point for the analysis of the question raised above.

The invocability of self-defence by troop-contributing States in case of armed attack against the forces of an international organization will be examined here, having in mind armed forces presenting the complex legal status as briefly referred to above. In this respect, United Nations peacekeeping forces represent a model of this type of forces, though the present study does not purport to examine specifically the legal regime governing the activity of United Nations forces. When the armed force of an international organization is composed of individuals having exclusively the status of organs or agents of that organization, as in the case when members of the force are enlisted individually by the organization, there seems to be little doubt that only the organization may be entitled to act in self-defence. ${ }^{7}$ Conversely, when the national contingent is not put at the disposal of the organization and remains under the command and control of its State, that contingent exclusively acts as an organ of the contributing State. This State will therefore be the only subject entitled to invoke self-defence in case of armed attack. This is irrespective of whether the State, when deploying its armed forces, has relied on a recommendation or authorization of an international organization, or not. ${ }^{8}$

\footnotetext{
7) Seyersted, supra nota I, p. 405.
}

8) The fact that an organ of a State took certain conduct in reliance on the recommendation or authorization of an organization does not imply that that conduct is to be attributed to the organization or that the organization is entitled to act externally as bearer of rights in respect to this organ. With regard to the question of attribution of internationally wrongful acts, this view has been clearly upheld by the International Law Commission. See Report of the International Law Commission, supra note 3, p. 57. For a different view see, however, the decision of the European Court of Human Rights of 2 May 2007 in the cases Behrami $\&$ Behrami v. France and Saramati v. France, Germany \& Norway (text available at <www. echr.coe.int $>$ ), where the Court found that conduct of military forces of States acting under authorization of the Security Council was to be attributed exclusively to the United Nations. If one accepts the European Court's view that the United Nations is the only subject which bears responsibility for acts of the military forces of States acting under authorization of the Security Council, it seems that the invocability of self-defence by the sending States in case of armed attacks against national contingents should be denied. For some critical remarks concerning the criterion of attribution applied by the European Court, see Report of the International Law Commission, Sixty-first Session, supra note 3, p. 67. See also Pierre Klein, "Responsabilité pour les faits commis dans le cadre d'opérations de paix et étendue du pouvoir de contrôle de la Cour européenne des droits de l'homme: quelques considerations 


\section{The Use of Force against Russian Peacekeepers in Georgia: The Assessment of the EU Fact-Finding Mission}

Among the many issues addressed in the 2009 Report of the EU Fact-Finding Mission in Georgia, one concerned the legal qualification of the use of force by Russia against Georgia in August 2008. In a letter of II August 2008, Russia had informed the Security Council that its armed intervention in the territory of Georgia was justified as an action in self-defence under Article 5I of the United Nations Charter. According to Russia that intervention pursued "no other goal but to protect the Russian peacekeeping contingent and citizens of the Russian Federation ... and to prevent future armed attacks against them". ${ }^{9}$ The peacekeeping contingent referred to in the letter was a Russian military unity forming part of the Joint Peacekeeping Forces for South Ossetia, which had been established under an agreement concluded in 1992 in Sochi between Georgia and Russia. The Joint Peacekeeping Forces consisted of unities coming from the Russian, Georgian and Ossetian sides. ${ }^{\text {IO }}$ Russia claimed that on 8 August 2008 Georgian troops attacked the peacekeepers' military premises in South Ossetia and that such attack constituted an armed attack under Article 5I of the Charter.

The EU Fact-Finding Mission recognized that a military intervention against the land forces of a State stationing on the territory of another State may constitute an armed attack which is apt to trigger the right of self-defence of the sending State. ${ }^{\text {II }}$ The EU Mission even conceded that,

\footnotetext{
critiques sur l'arrêt Behrami et Saramati', 53 Annuaire français de droit international (2007), p. 55; Paolo Palchetti, "Azioni di forze istituite o autorizzate dalle Nazioni Unite davanti alla Corte europea dei diritti dell'uomo: i casi Beharami e Saramati" 90 Rivista Di Diritto Internazionale (2007), pp. 689-690; Linos-Alexander Sicilianos, "Entre multilatéralisme et unilatéralisme: l'autorisation par le Conseil de securité de recourir à la force" 9 Recueil des cours (2008), pp. 376 et seq.; Aurel Sari, "Jurisdiction and International Responsibility in Peace Support Operations: The Behrami and Saramati Cases", 8 Human Rights Law Review (2008), p. I64.

9) Letter from the Permanent Representative of the Russian Federation to the United Nations addressed to the President of the Security Council, in August 2008, UN Doc. S/2008/545.

г) For a description of the functioning of the Joint Peacekeeping Force, see Report of the Independent International Fact-Finding Mission on the Conflict in Georgia, vol. I, p. I4, para. 6, <www.ceiig.ch>.

II) Report, supra note Io, vol. II, p. 265. The EU Mission referred to Article 3(d) of the General Assembly Resolution “Definition of Aggression” (Resolution 33I4 (XXIX) of 1974) in order to qualify the assault against Russian peacekeepers as an armed attack.
} 
"[i]f the Russian allegations were true, the attack by Georgian armed forces on the Russian military base would surpass the minimum threshold in scale of effects required for an 'armed attack' in the sense of Article 5I of the UN Charter". ${ }^{22}$ In the end, however, it found that the Russian military intervention was unlawful as it did not comply with the requirements of necessity and proportionality. In the view of the EU Mission, "[a]s an act of self-defence against the attack on the Russian military bases, the only admissible objective of the Russian reaction was to eliminate the Georgian threat for its own peacekeepers". ${ }^{13}$

For the purposes of the present study, the most interesting issue addressed in the Report was whether an armed attack directed against Russian troops forming part of a peacekeeping force provided under the Sochi Agreement could be considered as an armed attack triggering Russia's right of selfdefence. In this regard, the EU Mission's finding that "the Georgian attacks against the Russian peacekeepers' base would equal an attack on an ordinary Russian base in foreign territory" ${ }^{14}$ was mainly based on the assessment of the degree of authority and control exercised by Russia over the troops forming part of this peacekeeping operation. In particular, the EU Mission first took care to stress that "[ $t$ ]he peace-keeping operation here was not a UN organ that acted under the overall control of the United Nations". Is To substantiate this observation, relevance was given to the fact that Russia maintained "the ultimate military command" over its troops and that under the Sochi Agreement the Commander of the Joint Forces, who had the power to coordinate the activity of the different military units involved in the peacekeeping mission, was always to be from the Russian side. Having considered all these elements, the EU Mission concluded by noting that " $[t]$ he entire legal arrangement suggests that actions of the peacekeeping forces were attributable to their respective states, and that the peacekeeping forces in that respect resembled 'state instrumentalities' which may legally be the object of an armed attack". ${ }^{16}$

\footnotetext{
12) Ibid., p. 269.

13) Ibid., p. 274.

14) Ibid., p. 268.

15) Ibid., p. 267.

16) Ibid., p. 268.
} 
The latter assertion is somewhat strange because it gives the impression that attribution of the acts of a national contingent to its State is the decisive element to determine whether such contingent may be considered as a 'State instrumentality' for the purposes of self-defence. In fact, what matters for that purpose is whether the contingent was acting as an organ of its State. Attribution of the conduct of these forces to the State is simply a consequence of their status as organs of the State. Anyway, it is difficult not to agree with the conclusions reached by the EU Mission regarding the status of Russian peacekeepers. Taking into account the institutional arrangements governing the activity of these forces, there is little doubt that they were not placed at the disposal of another State or another organization and acted exclusively as organs of Russia. Under such circumstances, as we have seen, Russia appeared to be entitled, at least in principle, to act in self-defence in case of an armed attack by another State against these troops.

The Report's appraisal of the situation characterizing United Nations peacekeeping forces appears more debatable. By contrasting the peacekeeping operation under the Sochi Agreement with United Nations peacekeeping operations, the Report impliedly suggests that in the latter case national contingents cannot be considered as 'State instrumentalities' for the purposes of self-defence. This would be so, in the view of the EU Mission, because in such case peacekeeping operations are United Nations organs that act "under the overall control of the United Nations" ${ }^{17}$ This conclusion, however, is not based on an adequate analysis of the legal status of military forces, such as the United Nations peacekeeping forces, which are composed of national contingents placed by their sending States at the disposal of an international organization.

\section{The Legal Status of National Contingents Put at the Disposal of an International Organization and its Implications for the Purposes of Self-Defence}

The view that the international organization has the sole international representation and responsibility for the activity of armed forces placed at its disposal by Member States finds some support in literature as well as in judicial decisions. With regard to the United Nations peacekeeping

17) Ibid., p. 267. 
forces, this view has been sometimes premised on the fact that these forces are accorded the status of organs of the organization. For instance, in its decision in the Behrami and Saramati cases the European Court of Human Rights found it sufficient to refer to the status of UNMIK as "a subsidiary organ of the UN created under Chapter VII of the Charter" to justify its finding that the acts of UNMIK were attributable exclusively to the United Nations. ${ }^{18}$ Certain authors who hold the view that the international responsibility for the conduct of the United Nations peacekeeping forces is borne exclusively by the United Nations seem to rely on the argument that national contingents are placed under the exclusive authority of the organization. ${ }^{19}$

These arguments are scarcely tenable. The fact that the armed force of an organization is accorded the status of organ under the rules of that organization does not exclude national contingents from acting at the same time as organs of their respective States. ${ }^{20}$ Nor does it exclude that certain acts of a national contingent composing the force may be attributed to its sending State. As we shall see, what matters for the purposes of attribution is to establish which subject has authority over the contingent in relation to the specific acts under consideration. The view that national contingents are placed under the exclusive authority of the United Nations and cease to act as organs of their respective State does not reflect the way in which the transfer of powers over the troops is arranged between the United Nations and the contributing States. In fact, national contingents, while put at the disposal of the United Nations, continue to act simultaneously as organs

\footnotetext{
18) Decision (Grand Chamber) of 2 May 2007, supra note 8, para. I4I.

19) Seyersted, supra note I, p. 429. It might be here observed that, in principle, when national contingents are fully seconded to an organization, that organization will no doubt be the only subject which can be regarded as bearing international rights and obligations in respect to the force. Moreover, in such a case all conduct of the force will be attributed to the organization.

20) The possibility that an individual or an entity, which has the status of organ of the lending State, is given the status of organ also within the internal legal order of the receiving State, "so that at a given moment he will formally be an organ of two different States at the same time", was acknowledged by Ago. In respect to such a case, Ago observed that, "in spite of this formal situation, the person in question will in fact be acting only for one of the States or at all events in different conditions for each of them". Roberto Ago, "Third Report on the Responsibility of States for Internationally Wrongful Acts", Yearbook of the International Law Commission (I97I) Vol. II-I, p. 268, note 4OI.
} 
of their respective States. This element has been duly highlighted by the International Law Commission in its commentary to Article 6 of the Draft Articles on the Responsibility of International Organizations. Referring to the situation in which "the lent organ or agent still acts to a certain extent as organ of the lending State", the Commission noted that " $\mathrm{t}]$ his occurs for instance in the case of military contingents that a State places at the disposal of the United Nations for a peacekeeping operation, since the State retains disciplinary powers and criminal jurisdiction over the members of the national contingent" ${ }^{21}$ In the Nissan case the same view was expressed by Lord Morris of Borth-y-Gest in the following terms: "though national contingents were under the authority of the United Nations and subject to the instructions of the commander, the troops as members of the force remained in their national service. The British soldiers continued, therefore, to be soldiers of Her Majesty". ${ }^{22}$ In fact, the retention of certain powers by the sending State implies that, as the United Nations Secretary-General put it, "United Nations command is not full command" ${ }^{23}$ The authority of the United Nations over the forces is confined to operational command, while important command functions such as the exercise of disciplinary powers and criminal jurisdiction over the forces "remain the purview of their national authorities". 24

The fact that national contingents act simultaneously as organs of the organization and as organs of their respective States has important legal consequences. With regard to the question of international responsibility, the International Law Commission has clarified that in this type of situations attribution is based on the factual control over the conduct of the force. ${ }^{25}$ This seems to imply that an act of the force is to be attributed either to the

\footnotetext{
21) Report of the International Law Commission, Sixty-first Session, supra note 3, p. 62.

22) Attorney-General v. Nissan, [1969] I All ER 629, p. 646.

23) Comprehensive Review of the Whole Question of Peace-Keeping Operations in All Their Aspects, Command and Control of United Nations Peace-Keeping Operations, Report of the Secretary-General, 2I November 1994, A/49/68I, p. 2. See also United Nations Peacekeeping Operations: Principles and Guidelines (UN, 2008), p. 68, <www.peacekeepingbestpractices. unlb.org/Pbps/Library/Capstone_Doctrine_ENG.pdf>.

24) Comprehensive Review, supra note 23, p. 3.

25) Article 6 of the Draft Articles on the Responsibility of International Organizations, adopted on first reading in 2009 , provides that " $[t]$ he conduct of an organ of a State or an organ or agent of an international organization that is placed at the disposal of another
} 
organization or to the sending State depending on whether that force, when taking that act, was acting under the control of the organization or of the State. ${ }^{26}$ According to some authors, however, dual attribution would better reflect the way in which, at least in the case of United Nations peacekeeping operations, the power of control over the troops is distributed between the contributing States and the receiving organization. This would be so, in particular, because of the control retained by States over the operational employment of their troops. ${ }^{27}$

The fact that national contingents continue to act as organs of the sending States seems to have implications also with regard to the legal entitlement of the sending States to invoke rights in relation to the activity of their contingents. Some authors have argued that the right of States in situations of this type would essentially be confined to the right of diplomatic protection

international organization shall be considered under international law an act of the latter organization if the organization exercises effective control over that conduct".

26) The commentary to Article 6 specifies that " $t]$ he criterion for attribution of conduct either to the contributing State or organization or to the receiving organization is based according to article 6 on the factual control that is exercised over the specific conduct taken by the organ or agent placed at the receiving organization's disposal". Report of the International Law Commission, Sixty-first Session, supra note 3, p. 63. This view is also shared by several authors. See Moshe Hirsch, The Responsibility of International Organizations toward Third Parties (Martinus Nijhoff Publishers, Dordrecht, 1995), p. 64 et seq.; Klein, supra note I, p. 379 et seq.; Michael Bothe and Thomas Dörchel, "UN Peacekeeping", in Dieter Fleck (ed.), The Handbook of the Law of Visiting Forces (Oxford University Press, Oxford, 20oI), p. 502; Stefano Dorigo, "Imputazione e responsabilità internazionale per l'attività delle forze di peacekeeping delle Nazioni Unite", 85 Rivista di diritto internazionale (2002), p. 903 et seq.; Marten Zwanenburg, Accountability of Peace Support Operations (Martinus Nijhoff Publishers, Leiden/Boston, 2004), p. 51 et seq.

27) Luigi Condorelli, "Le statut des forces de l'ONU et le droit international humanitaire", 78 Rivista di diritto internazionale (1995), p. 893 et seq.; ID, "Conclusions générales", in Mathias Forteau (ed.), La soumission des organisations internationales aux normes internationales relatives aux droits de l'homme (A. Pedone, Paris, 2009), p. I42; Christopher Leck, "International Responsibility in United Nations Peacekeeping Operations: Command and Control Arrangements and the Attribution of Conduct", Io Melbourne Journal of International Law (2009), p. I et seq.; Tom Dannenbaum, "Translating the Standard of Effective Control into a System of Effective Accountability: How Liability Should Be Apportioned for Violations of Human Rights by Member State Troops Contingents Serving as United Nations Peacekeepers", 5 I Harvard International Law Journal (2010, forthcoming). On the question of whether the International Law Commission's Draft Articles on the Responsibility of International Organizations recognizes the possibility of dual attribution, see Pierre Bodeau-Livenec et al, "Note", 102 American Journal of International Law (2008), p. 329. 
in respect of nationals who are members of the armed force of the international organization. ${ }^{28}$ However, this view does not take into account the status of national contingents as organs of the sending States. If this element is adequately considered, then it may be held that in principle a sending State is entitled to invoke not only those rights based on the nationality of the injured individuals but also the rights based on the status of the troops as organs of that State. ${ }^{29}$

The latter aspect is most significant for the purposes of assessing whether a sending State may be entitled to use force in self-defence in cases of armed attack against its national contingent acting within the context of an operation established by an international organization. Should one accept that the right of protection belonging to the sending State is restricted to diplomatic protection in relation to injuries to its nationals, then the invocability of self-defence by that State would be ruled out. An attack against nationals abroad could hardly be regarded as an armed attack which triggers the right of self-defence under Article 5I of the Charter. ${ }^{30}$ It may be suggested that the use of force by the sending State could be justified on the ground of the need to rescue and protect nationals abroad. Indeed, in order to justify its military intervention in Georgia, the Russian Federation made also reference to the need to protect Russian citizens. As is well known, however, it is highly doubtful that, under general international law, the protection of nationals abroad can justify the use of force against another State. As it was observed by the EU Mission in this respect, "State practice and opinio iuris do not support a specific right to intervention in order to protect or rescue own nationals abroad as an independent legal title in itself" ${ }^{3 \mathrm{I}}$

If, on the contrary, one recognizes that the right of protection belonging to the sending State goes beyond diplomatic protection as it also encompasses the entitlement to invoke those rights which are based on the status of the

\footnotetext{
28) Seyersted, supra note I, p. 429; Zwanenburg, supra note 26, p. 38.

29) Condorelli, "Le statut des forces de l'ONU", supra note 27, p. 891.

30) For the view that "[u]nlike military units, neither diplomatic missions nor individual nationals are considered 'external positions' of a State that can be objects of an armed attack", see Albrecht Randelzhofer, "Article 5r", in Bruno Simma (ed.), The Charter of the United Nations: A Commentary (Oxford University Press, Oxford, 2nd ed., 2002), p. 80I. See also Roucounas, supra note I, p. 9I. For a different view see Antonio Cassese, "Article 5I", in Cot et al, supra note I, p. I350.
}

31) Report, supra note Io, vol. II, p. 286. 
contingent as organ of the State, in principle the possibility that the sending State is entitled to invoke self-defence in response to an armed attack against its national contingent cannot be ruled out. Indeed, the permanence of an institutional link between the contingent and the sending State constitutes an element that lends some support to the proposition that, at least under certain circumstances, an armed attack against that contingent may be regarded as an attack against the State for the purposes of self-defence. In this respect, the fact that the international organization may be entitled to act in self-defence does not imply that the same right must be denied to the sending State. Referring to the problem of the "competition between the State's right of diplomatic protection and the Organization's right of functional protection", the International Court of Justice, in its advisory opinion in the Reparation for Injuries case, acknowledged that, "[i]n such a case, there is no rule of law which assigns priority to the one or to the other, or which compels either the State or the Organization to refrain from bringing an international claim". ${ }^{32}$ It may be held that the solution retained by the International Court of Justice with regard to that problem may be regarded as applying also to the situation at hand. ${ }^{33}$

\section{Practice Concerning the Use of Force to Protect the Armed Forces of an International Organization}

As far as this author is aware, practice does not offer examples in which a State invoked self-defence to justify resort to force in order to repel an armed attack against a military contingent put by that State at the disposal of an international organization. Here again, the lack of precedents is not surprising if one considers the limited number of international organizations having the competence to establish and deploy military forces. Moreover, as it will be shown, there seem to be other factors which may contribute to make this situation very unlikely to arise in practice. ${ }^{34}$

\footnotetext{
32) Reparations for Injuries Suffered in the Service of the United Nations, Advisory Opionion, ICJ Reports 1949, p. 185. On the question of the relationship between the right of functional protection of an international organization and the right of diplomatic protection of the State of nationality of the injured agent, see John Dugard, Fifth Report on Diplomatic Protection, A/CN.4/538, p. II et seq.

33) Condorelli, "Le statut des forces de l'ONU", supra note 27, p. 89i et seq.

34) Statements by States or international organizations claiming that sending States would be entitled to invoke self-defence in cases of an armed attack against their national contingents
} 
When considering the different scenarios arising out of situations of military attack against peacekeeping forces, the United Nations, while constantly recognizing that such forces are entitled to use force in self-defence, ${ }^{35}$ has never contemplated the possibility of unilateral actions in self-defence by the sending States or by States acting on behalf of the sending States. Arguably, a strong reluctance to accept this possibility is to be expected from the United Nations. A unilateral use of force by the sending State would undermine the authority and control of the organization over the operation. It could also imperil the perception of the operation as one having strictly an international character and reflecting the will of the United Nations. ${ }^{36}$

On the other hand, there is little doubt that, particularly when a peacekeeping force is involved in a situation of military confrontation, the protection of national contingents represents a matter of major concern for States contributing troops to the organization. When situations of this kind had arisen, sending States did not fail to voice their concern by addressing protests or taking position against those responsible for the military attacks. ${ }^{37}$ With regard to the type of action that sending States may take to protect their troops, a very far-reaching stance was taken by the United States in an official document issued in 1994, in the aftermath of the decision of that

\footnotetext{
are also rare. See, however, the observation of Portugal according to which, when an international organization is administering a territory or deploying a military force, "the State whose forces were in territory or the individual members of those armed forces were the entities exercising self-defence": A/C.6/6I/SR.I4, para. 74.

35) See, e.g., United Nations Peacekeeping Operations, supra note 23, p. 34. Admittedly, as noted supra note I, when recognizing the existence of a right of self-defence in the context of peacekeeping operations, the United Nations generally employ that concept to refer to fact that in principle peacekeepers are entitled to resort to force to defend themselves or their mandate. This is also the meaning given to such term in the abovementioned document.

36) On the importance for the United Nations of securing that a peacekeeping operation functions as one integrated unit reflecting the will of the international community as a whole, see Comprehensive Review of the Whole Question of Peace-Keeping Operations, supra note 23, p. 3 , para. 7 .

37) See, e.g., the statement issued at the end of the meeting convened in London on 2I July 1995 by the foreign and defence ministers of the five-member Contact Group and II other main contributors to the United Nations peacekeeping force in the former Yugoslavia, where these States strongly condemned the armed attacks conducted by Bosnian Serbs against the United Nations' 'safe areas', stressing that such attacks affected the national interests of troop-contributing States. See Maurice Torrelli, "Les zones de sécurité, , Io6 Revue générale de droit international public (1995), p. 842, note IIO.
} 
State to withdraw its troops from the United Nations' mission in Somalia. In this document, the government of the United States made it clear that, whenever forces of the United States will be placed under the operational control of a United Nations commander, certain "fundamental elements of U.S. command" would always apply..$^{38}$ These elements would include, in particular, the "right" of the United States "to take whatever actions it deems necessary to protect U.S. forces if they are endangered". Although the United States government did not expressly refer to military actions to protect United States forces against an armed attack, this statement is broad enough that a reference to that situation appears to be implied. Certainly, when a State subjects its participation to a peacekeeping force to conditions such as those indicated by the United States in the abovementioned document, the organization could always decide to decline the offer by that State. ${ }^{39}$ Yet, independently of what would be the attitude of the receiving organization, the question to be asked here is whether, under the international rules on the use of force, the sending State would be entitled to resort to military force to protect a national contingent which is placed under the operational command and control of the organization.

Before turning to this issue, it may be interesting to note that, in situations in which United Nations peacekeeping forces were made the object of armed attacks, their protection has sometimes been given by States operating outside the United Nations command structure. ${ }^{\circ}$ In certain cases, the Security Council authorized States to conduct air strikes or other military actions to confront and deter the threat and use of armed force against United Nations forces. This is the case of Resolution 836 (1993), which, in addition to authorizing UNPROFOR, "acting in self-defence, to take the necessary measures, including the use of force, in reply to bombardments against the safe areas", also authorized States to take, "under the authority of the Security

\footnotetext{
38) “Key Elements of the Clinton Administration's Policy on Reforming Multilateral Peace Operations", 33 International Legal Materials (1994), p. 809.

39) See Comprehensive Review of the Whole Question of Peace-Keeping Operations, supra note 23, p. 3, para. 7: "In some exceptional cases, troops have been offered with prior restrictions of a nature which would have severely compromised the contingents' usefulness, and offers made on those conditions have had to be declined".

40) See, e.g., Administrative and Budgetary Aspects of the Financing of the United Nations Peacekeeping Operations: Financing of the United Nations Peacekeeping Operations. Report of the Secretary-General, 20 September 1996, A/5I/389, p. 6, paras I7-I9.
} 
Council and subject to close coordination with the Secretary-General and UNPROFOR, all necessary measures, through the use of air power, ... to support UNPROFOR in the performance of its mandate". ${ }^{\mathrm{I}}$ While in this type of situation military intervention by States, insofar as it purports to respond to armed attacks against United Nations forces, comes close to an action in self-defence, it is clear that the legal basis for such use of force is to be found in the authorization by the Security Council. ${ }^{42}$ In this respect, an authorization by the Security Council may operate to a certain extent as an alternative legal basis for an armed intervention by States aimed at the protection of United Nations forces. ${ }^{43}$ It may be expected, at least in the context of the United Nations, that if the need arises for a military response to defend United Nations forces, an authorization to use force given by the Security Council would be the most suitable way to allow States to intervene.

\section{The Intention of the Attacking State as a Criterion for Determining the Existence of an Armed Attack against the Troops- Contributing State}

Absent indications from practice, the invocability of self-defence by the sending State must be assessed primarily taking into account the rationale underlying the application of the rule of self-defence in case of an armed attack against the military forces of a State deployed abroad.

The fact that the use of force against certain State organs or installations abroad may amount to an armed attack triggering the right of self-defence is generally premised on the idea that these organs or installations constitute external manifestations of a State which, like State territory, enjoy protection

\footnotetext{
41) Security Council Resolution 836 (1993) of 4 June 1993, respectively para. 9 and para. II of the operative part.

42) See in this respect the observations made by Linos-Alexander Sicilianos, "Le contrôle par le Conseil de sécurité des actes de légitime défense", in Le Chapitre VII de la Charte des Nations Unies (Paris, 1995), p. 94.

43) In fact, if the Security Council authorizes States to use force to defend a peacekeeping force which is made the object of an armed attack, such measure would have the effect of terminating the possibility of invoking self-defence. Under Article 5I of the Charter, the right of self-defence continues "until the Security Council has taken measures necessary to maintain international peace and security". No doubt, an authorization to use force constitutes a measure terminating the right of self-defence within the meaning of Article 5I.
} 
in relation to the prohibition to use force. ${ }^{44}$ Armed forces are certainly included among such external manifestations of the State. Thus, an armed attack against military units of the State operating abroad is equivalent, for the purposes of self-defence, to an attack against State territory.

Moving from this premise, it seems that when a military unit of a State is placed at the disposal of an organization and is deployed abroad within the context of a military mission established by that organization, the identification of such unit as an external manifestation of the State is questionable. It is true that national contingents, to a certain extent, continue to act as organs of their respective States. However, this element, in itself, can hardly be considered as decisive as it is counterbalanced by the fact that these contingents also act as an organ of the organization. In many respects, since for the duration of their participation to the military operation national contingents act in the discharge of functions assigned to them by the organization and under its operational command and control, the elements linking national contingents to the organization appear to be preponderant. Under these circumstances, it seems difficult to admit that the use of force against a national contingent can be readily equated to an armed attack against the sending State. This is the more so since in most cases such use of force will be mainly motivated by the intention of the attacking State to prevent troops from discharging their functions under the mandate assigned to them by the organization. In this kind of situation, while the international organization can certainly be considered to be a victim of armed attack triggering its right of self-defence, the same does not necessarily hold true for the sending State. In the absence of circumstances indicating that the use of force was specifically aimed at targeting the sending State an important element for considering that State as a victim of an armed attack seems to be lacking.

A different conclusion may be advocated if, on the contrary, the attacking State uses force against a national contingent specifically in order to target the sending State. This intention of the attacking State, coupled with the fact that the attacked military unit retains the status of an organ of the

\footnotetext{
44) See Randelzhofer, supra note 30, para. 24; Yoram Dinstein, War, Aggression and Self-Defence (Cambridge University Press, Cambridge, 3rd ed., 200I), p. 177; Olivier Corten, Le droit contre la guerre (A. Pedone, Paris, 2008), p. 6I4; Roucounas, supra note I, p. 9I; Chatham House, Principles of International Law on the Use of Force by States in Self-Defence, p. 5, <www. chathamhouse.org.uk>.
} 
sending State, may justify the recognition for the latter State of a right to protect its contingent. In particular, it may be argued that since the military contingent was attacked because it represented the sending State, that State may be regarded as being the victim of an armed attack triggering the right of self-defence.

Thus, the intention of the attacking State seems to play a major role in assessing whether a sending State may be considered as entitled to act in self-defence in the case of an armed attack against a military unit which that State had placed at the disposal of an international organization. The importance of this element as a criterion for determining whether an action involving the use of force amounts to an armed attack finds support in practice. ${ }^{45}$ Most prominently, in its judgment in the Oil Platforms case, the International Court of Justice held the view that a missile attack against a US-flagged vessel, allegedly carried out by Iran at a time in which that State was at war with Iraq, could not amount to an armed attack because there was no evidence that such vessel was specifically targeted; ${ }^{46}$ similarly it excluded that the mining of another US-flagged vessel could be considered as an armed attack since it had not been established that "the mine struck by the Bridgeton was laid with the specific intention of harming that ship, or other United States vessels". ${ }^{47}$ Interpreting the Court's dictum in the light of the particular context in which the attacks against the United States vessels took place, the EU Fact-Finding Mission in Georgia observed that "the requirement of a specific intention to target the state which claims self-defence is especially important if the asserted attack occurs, as here, in a military conflict between two other parties". ${ }^{8}$ Along the same line it could be held that the requirement of a specific intention to target the State plays

\footnotetext{
45) For an examination of the pertinent practice, see, in particular, Corten, supra note 44, p. Ioo et seq. On the relevance of the intention of the attacking State for the purposes of determining whether certain conduct involving the use of force may be qualified as an armed attack, see also Roucounas, supra note I, p. IIO; Chatham House, supra note 44, p. 6.

46) Oil Platforms (Islamic Republic of Iran v. United States of America), ICJ Reports 1993, p. I9I, para. 64.

47) Ibid.

48) Report, supra nota Io, vol. II, p. 266. Similarly, referring to the Court's statement, Christine Gray, International Law and the Use of Force (Oxford University Press, Oxford, 3 rd ed., 2008), p. I45, observed that "the Court apparently decided that harm by a mine or a missile constitutes an armed attack on a third State during a conflict between two other States only if the attack was specifically aimed at that third State".
} 
a crucial role in situations in which, given the complex legal status of the armed forces which have been made the object of the armed attack, it is not clear whether these forces were attacked because of the functions they performed under the command and control of the organization or because they represented the State at which the attack was aimed. In the latter case the sending State may be regarded as being a victim of an armed attack triggering the right of self-defence.

While the attacking State's intention appears to constitute the decisive criterion by which to assess the existence of the sending State's right to act in self-defence, it may be asked whether other situations may be envisaged in which the sending State would be entitled to use force to defend its national contingent. In particular, the question could be raised of whether, if the international organization fails to take any action in response to the military attack, the sending State could then be considered to be entitled to use force. There is certainly some merit in the idea that sending States would retain some sort of residual right of self-defence in case of inaction of the organization. This would result in a mechanism that gives the organization the possibility to first assert its right to act in self-defence while at the same time avoiding the risk that, because of the organization's inaction, no military protection may be provided to the forces which have been made the object of the armed attack. While this mechanism has clear practical advantages, it is difficult to see on which legal basis the existence of such a residual right of self-defence can be premised. Lacking any element of practice, it seems that this argument could only be regarded as de lege ferenda. ${ }^{49}$

\footnotetext{
49) It is interesting to note that, when considering the problem of the relationship between an international organization's right of functional protection in respect to its agents and a State's right of diplomatic protection in respect of a national who is an agent of the organization, the International Law Commission's Special Rapporteur on Diplomatic Protection, John Dugard, had considered the possibility to include in the draft articles a provision which gave priority to the organization's functional protection while recognizing the possibility for States to exercise their right of diplomatic protection "where that organization is unable or unwilling to exercise functional protection". See Dugard, supra note 32, p. II. In Dugard's view, this rule would introduce a "helpful method of reconciling competing claims" (at p. I7). He acknowledged, however, that there was no support for the principle of priority in international practice. The final text of the draft articles adopted by the International Law Commission in 2006 does not address the question of the protection of an agent of an international organization.
} 


\section{Conclusions}

Together with the question of the invocability of self-defence by an international organization, it may well be that also the question of the invocability of self-defence by the sending State of a military unit placed at the disposal of an international organization is destined to remain a theoretical issue. This notwithstanding, the question is one worth exploring, particularly because it contributes to shed some light on the complexity of the relationship existing between the sending State and the organization in the case in which a national contingent is not fully seconded to the organization.

The fact that, contrary to the view that is sometimes expressed, national contingents, while integrated in a force that acts as organ of the organization, also act as organs of their respective States raises a number of interesting questions. In recent years, the International Law Commission has attempted to clarify how responsibility for wrongful acts of these forces must be apportioned between the sending State and the receiving organization. Other problems have not yet received a comparable attention and are the subject of considerable legal uncertainty. This remark applies, in particular, to the question of determining which rights, if any, a State may be entitled to claim in relation to the activity of one of its organs which has been placed at the disposal of an international organization, and what is the relationship between the position of the sending State and that of the receiving organization in respect to the protection of rights arising in connection with the activity of the lent organ.

Without purporting to give an answer to the foregoing general questions, the present study constitutes an attempt to offer some elements for assessing the implications deriving from a military contingent's dual status as both the State's and the organization's organ with regard to the question of the allocation of the right of self-defence. The suggested solution, which is based on the consideration of both the contingent's dual status and the rationale underlying the rule on self-defence, does not exclude the possibility for the sending State to invoke self-defence nor does it recognize for that State an unfettered right to intervene in self-defence whenever the national contingent is made the object of an armed attack. By admitting the invocability of self-defence by the State only in those cases in which the armed attack is clearly aimed at targeting that State, this solution seems to strike a reasonable balance between the interest of the international organization in preserving its autonomy in the direction of the military operations and the interest of the State to intervene whenever the attack put its security at risk. 